American Journal of Applied Sciences 7 (1): 1-12, 2010

ISSN 1546-9239

(C) 2010 Science Publications

\title{
Nutritional Value of the Maize Stalk Borer and American Bollworm as Unconventional Protein Sources
}

\author{
A.E. Ghaly and F.N. Alkoaik \\ Department of Agricultural Engineering, College of Food and Agricultural science, \\ King Saud University, Riyadh, Kingdom of Saudi Arabia
}

\begin{abstract}
Problem statement: The maize stalk borer and American bollworm were grown in an artificial media to evaluate their potential as human food sources. Approach: Both cultures were started from moths and the life cycle and culture structures were evaluated. Results: The larvae of both insects reached maximum weight and maximum length at the same time. The growth rate of the youngest larvae was found to be the highest and the increase in the body weight during the growth period appeared to be linear. The larvae of these insects started to decrease in weight after they reached the maximum size. For efficient systems for the commercial production of the maize stalk borer and the American bollworm, the larvae should be harvested when they are 39 and 21 days old, respectively. The protein contents were 38.0 and $33.0 \%$ and the fat contents were 14.5 and $14.4 \%$ for the dried larvae of the American bollworm and maize stalk borer, respectively. The larvae of both insects contained the essential amino acids and minerals. Only 10\% mortality was observed with older larvae of both species. A system where eggs are separated from adults and hatched in separate chambers would alleviate the possible danger of losing the population due to microbial infection. The high moisture content of the larvae (60.4-61.0\%) could cause handling and storage problems. Drying and grinding the larvae would reduce them to easily manageable forms and would improve their marketability as novel food. Conclusion: The results obtained from this study show the potential of using insects as a protein source for human consumption to alleviate protein deficiency in many parts of the world, especially in Latin America, Africa and Asia. Further research is required to evaluate their growth characteristics on low substrates. Future research should also evaluate environmental parameters such as temperature, relative humidity and heat and $\mathrm{CO}_{2}$ production on food consumption and protein yield per gram substrate. This information will aid in the design of optimal production systems.
\end{abstract}

Key words: Maize stalk borer, American bollworm, growth rate, protein, amino acids, fat, essential elements, human nutrition, artificial feed

\section{INTRODUCTION}

The world is coming to recognize the grim truth that ultimately the population growth will outstrip food suppliers with apocalyptic results. In 2000, 36 million people died due to hunger or as a result of hunger (FAO/SD, 2001). About $60 \%$ of the 10.9 million deaths each year among children under the age of five in the developing world are attributed to malnutrition (WHO, 2002). If the current average birth rate continues, the world's population will grow from the current 6.7-9.2 billion by the year 2050, most of which will be in the less developed countries of Latin America, Africa and Asia (WHO, 2007), the countries least able to feed their children. Feeding 9.2 billion people at the current dietary levels presents the staggering necessity of increasing the earth's food producing capacity to a rate never seen before.
Protein deficiency is one of the major nutritional problems in the developing world (Latham, 1997). Most foods rich in protein are also comparatively good sources of the other required nutrients (Eby and Dandy, 1962). If animal proteins supply part of the diet, the nutritional quality of the diet is generally enhanced because most animal proteins contain all the essential amino acids (cysteine, histidine, isoleucine, methionine, leucine, lysine, phenylalanine, methionine, tryptophan, tyrosine and valine) humans require, whereas most plant proteins lack one or more of these essential amino acids (NLM., 2007). Animal proteins are also a rich source of vitamin $B_{12}$ and minerals (Herbert, 1998). Because the body's need for protein is related to its rate of growth, the need for protein is much greater in infants than in older children or adults (Verkerk et al., 2007). There is agreement among scientists that protein 
malnutrition contributes to the high death rate among infants and children of the less developed countries and causes among the survivors debilitating weakness, higher susceptibility to disease and irreversible brain damage (Verkerk et al., 2007; Ramos-Elorduy, 1997).

The development of novel protein sources such as Fish Protein Concentrate (FPC) (Harrel et al., 1980; Pariser et al., 1977; Sikka et al., 1979), Single Cell Protein (SCP) (Tannenbaum, S.R. and D.K. Wang, 1975; Ferrianti and Fiechter, 1983) and Soybean Protein (SBP) (Mendez et al., 2002; Bhatia and Greer, 2008) have made significant contributions toward the alleviation of the world's protein deficiency (Kuijer et al., 1999). However, there is still an estimated one billion people suffering from protein deficiency and malnutrition (WHO/FAO., 2007). It is, therefore, necessary that similar success be obtained by utilizing what seems to be an inexhaustible supply of insects as a protein source for human consumption. Insects make up (on the average) about two-thirds of the food of our common land birds and two-fifths of the food of adult fresh water fish. Turkeys, hogs and other domestic animals are often fattened on insects (Flint and Metcalf, 1979). Therefore, insects can be reared on readily available low substrates to provide a sustainable and nutritional supply of protein for human consumption to alleviate the world protein deficiency and maintain the ever increasing human populations (Kok et al., 1991). Insects can be easily reared to efficiently convert low quality substrates to high quality proteins. Careful production, processing and marketing procedures would make insects as acceptable as FPC, SCP and SBP. This will require substantial innovation in food production and processing technologies (Verkerk et al., Pariser et al., 1977; DeFoliart, 1999).

Objectives: Although many reports have been made on eating the maize stalk borer and the American bollworm, very little information is available on the nutritional quality of these insects. These insects can be easily reared and handled in the laboratory to obtain information for the development of economically and technically feasible commercial production systems for their use as a source of protein for human consumption. The specific objectives of this study were: (a) to develop an artificial ration for production of viable cultures of the maize stalk borer (Busseola fusca) and the American bollworm (Heliothis armigera), (b) to establish viable and strong cultures of these insects, (c) to study the life cycle and culture structure of each insect, (d) to determine the growth rates of the larvae and (e) to evaluate the nutritional values of the larvae.

\section{MATERIALS AND METHODS}

Maize Stalk Borer (Busseola fusca): The maize stalk borer (Busseola fusca) belongs to the family of night flying moths. It is from the order Lepidoptera and the family Noctuidae. The insect is distributed worldwide and is found in all provinces of Canada. The maize stalk borer is almost a universal plant feeder attacking any plant large enough to shelter it and soft enough that it can bore into. Generally, it prefers field crops (such as corn, sorghum, sugar cane, cereals, tobacco) ragweed, grasses, flowers (such as dahlias, hollyhocks, hyer lilies and steers) and vegetables (such as rhubarb, mint, peppers, potato and tomato) where it tunnels in their stalks. Most of the damage caused to the corn plant is due to the direct result of the caterpillars making holes by burrowing in the pith of the stalks, causing the whole plant to wilt with tip leaves first turning yellow or brown and dying. Later in the season, the caterpillars get into the maize cobs allowing a secondary infection by fungi that cause further damage to the developing seeds (Ebenebe et al., 2000).

The life cycle of the maize stalk borer (Busseola fusca) includes four stages: Egg, larva, pupa and moth (Fig. 1) (USDA., 1899). The caterpillars hibernate over winter inside the old stem bases of the last season's maize plants. They pupate in the spring and remain in the form of pupae for 10 days until they emerge as adult moths. The adult moths leave their empty pupal skins in the stalks. The moths are darkish brownish grey and mostly fly in the evenings and early morning. Over a period of a few weeks, the female moth lays up to 800 eggs in batches in the fold of the maize leaves near the top of the funnels. A batch of eggs may comprise of 30-150 eggs on one plant. They are about $1 \mathrm{~mm}$ in diameter. They hatch after 7-10 days.
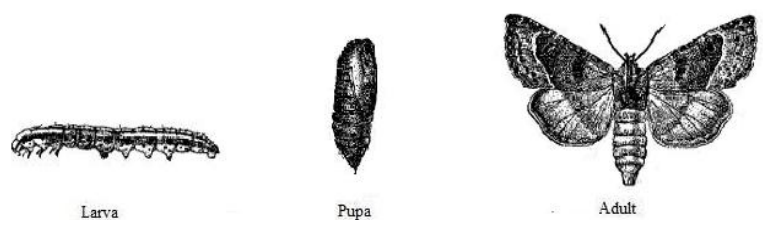

(a)
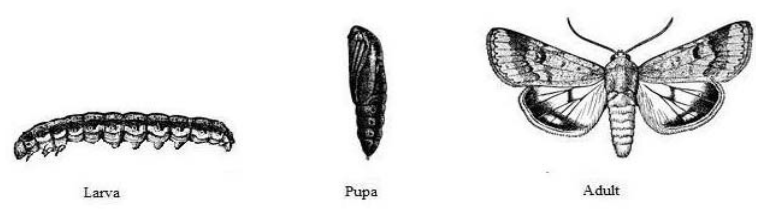

(b)

Fig. 1: Life cycle of insects; (a) Maize stalk borer (USDA, 1899) (b) American bollworm (Tracy, 1907) 
Table 1: Chemical analysis of the diets used in the study

\begin{tabular}{lcc}
\hline & Content (\%) & \\
Constituent & Starter diet & Mass rearing diet \\
\hline Water & 14.0 & 15.5 \\
Ash & 7.3 & 6.7 \\
Carbohydrate & 56.5 & 56.7 \\
Protein & 19.6 & 19.1 \\
Fat & 2.6 & 2.0 \\
\hline
\end{tabular}

The young larvae are deep purple or black in color. The larvae tend to migrate up and down the plant and away to adjacent plants before they are half grown. They grow to about $25-30 \mathrm{~mm}$ in length and become darker in color. They feed on leaves, flowers and cobs and are known as top grub. They go to another plant to attack it by making small holes in the base of the stem and eat out the center killing the plant. They feed inside the stem for 6 weeks and then pupate near the root of the plant. The pupa is brown and about $25 \mathrm{~mm}$ long. In about 2 weeks, the adult moth comes out of the pupa and starts the second generation by laying more eggs on the maize plant. There may be 2 and 3 generations in a season before overwintering (Ebenebe et al., 2000; Bijimarkers, 1985).

American bollworm (Heliothis armigera): The American bollworm (Heliothis armigera) belongs to the family of night flying moths. It is from the order Lepidoptera and the family Noctuidae. It is of worldwide distribution and is found in all provinces of Canada. It is the most important pest of agricultural crops causing extensive damage to cotton, maize, tobacco, tomato, sunflower, wheat, pigeon peas and cabbage. Damage is done when the temperature begins to rise in spring. The insects seldom attacks foliage but prefer more juicy plant materials such as tomato fruits, tobacco tips, cotton bolls and developing maize cobs. The insect is known by different names: on cotton and tomato it is known as the American bollworm, on maize it is known as the earworm and on tobacco it is known the a budworm (Dimietry, 2005).

The life cycle of the American bollworm (Heliothis armigera) includes four stages: Egg, larvae, pupa and moth (Fig. 1) (Tracy, 1907). The larva is a stout caterpillar of greenish or brownish color. The body is marked with two lines of darker color running length-wise along the sides of the back. The full grown larva is about $40-50 \mathrm{~mm}$ long. The caterpillars feed with their head inside the boll or tomato fruit with the posterior part of the body outside. The worm is cannibalistic, only one larva is found in one fruit. Pupation occurs in 7 days and the length of the pupation stage is influenced by temperature. The adult is a brown, nocturnal moth with a wing span of about 40 $\mathrm{mm}$. The moths rest during the day with the folded wings on tree trunks and fly out to lay eggs on the plants at night. In about 10-20 days, several hundred (1000) eggs are laid singly. The eggs hatch in 2-4 days. The larval stage lasts for 15-20 days (Dimietry, 2005; Robinson, 1987).

Growth medium: The proper consistency of the diet and provisions for an adequately balanced diet that contains the essential growth substances is necessary for the propagation of insects (Lipke, 1957; Gupta et al., 2004). A nutritionally complete diet for most insects must contain: (a) protein or essential amino acids, (b) carbohydrates, (c) fat or fatty acids (cholesterol), (d) vitamins (ascorbic acid, a-tocopherol, folic acid, inositol, nicotinamide, pantothenic acid, riboflavin, thiamine or vitamin A), (e) minerals and (f) water. In this study, two artificial diets were prepared (Table). The first was used for rearing young insect larvae for the propagation of starter culture and the determination of weight and length and the second was used for mass rearing of insects for the determination of nutritional value.

Starter diet: This diet was prepared according to the procedure described by Guptal et al. (2004); Haydaks (1936) with slight modification. The diet was prepared by mixing corn flour, whole wheat flour, wheat bran and dried yeast powder (3:3:3:1 ratio by weight). The dry mixture was combined with an equal part of fluid made of glycerine and honey (1:1 ratio by weight). The mixture was mixed thoroughly and then allowed to stand for $24 \mathrm{~h}$ before use. The diet was then placed in oviposition and egg hatching cages.

Mass rearing diet: The diet used for grown up caterpillars was made of corn flour, wheat bran, wheat germ, brewer's yeast, agar, milk, castor oil, chicken mash and water. The corn flour, wheat germ, wheat bran, brewer's yeast and agar (3:3:3:1:1 ration by weight) were mixed together, combined with an equal part of chicken mash and blended for 2 min. The mixture was combined with an equal part of fluid made of milk, castor oil and water (1:1:4 ration by weight), mixed thoroughly and cooked for $15 \mathrm{~min}$. The diet was then poured into the mass rearing cages and allowed to stand for $24 \mathrm{~h}$ to solidify before use.

Starter culture: The culture of the maize stalk borer was started from adults emerging from old corn stalks whereas the culture of the American bollworm was started from adults emerging from old tomato plant material. Both infected materials were collected from infected fields in Truro, Nova Scotia. 
Rearing moths: Rearing moths was done in an environmentally controlled chamber (VWR Environmental Chamber, Model No. 2020, Shelden Manufacturing Company Inc., Cornelius, Oregon) at a temperature of $28^{\circ} \mathrm{C}$, a relative humidity of $70 \%$ and a photoperiodic regime of $10 \mathrm{~h}$ of light and $14 \mathrm{~h}$ of darkness. Adult moths from each species were used for egg-laying. The starter medium was placed in the oviposition cages $(60 \mathrm{~cm}$ long $\times 40 \mathrm{~cm}$ wide $\times 25 \mathrm{~cm}$ deep plastic container with perforated sides and cover) and arranged to provide the greatest surface area. Ten seeding adults from each insect species were placed over the medium in separate oviposition cages and used to produce the next generation. Waxed paper sheets were provided for the moths to lay their eggs.

Hatching of eggs: The starter medium was placed in each of the egg hatching chambers $(40 \mathrm{~cm}$ long $\times 40 \mathrm{~cm}$ wide $\times 25 \mathrm{~cm}$ deep plastic container with perforated sides and cover). The waxed papers (with eggs) were collected from the oviposition cages and the number of eggs per waxed paper sheet was estimated for each insect species. 100 eggs from each container were placed in several petri dishes and left on the top of the medium. The egg hatching chambers were placed in an environmentally controlled chamber (VWR Environmental Chamber, Model No. 2020, Shelden Manufacturing Company Inc., Cornelius, Oregon) at $28^{\circ} \mathrm{C}, 70 \%$ relative humidity and a photoperiodic regime of $10 \mathrm{~h}$ light and $14 \mathrm{~h}$ of darkness. Emerging larvae were isolated and 10 larvae were selected for the study of growth rate and life cycle while the rest of the larvae were mass reared using the mass rearing medium for the determination of nutritional value.

Growth rate determination: Ten larvae from each species were used for the length and weight measurements and growth rate determination. Each group of larvae were placed in separate rearing cages (60 $\mathrm{cm}$ long $\times 45 \mathrm{~cm} \times$ wide $\times 25 \mathrm{~cm} \times$ deep plastic containers with perforated plastic sides and cover) and reared on the prepared starter diet. The containers were placed in the growth chamber (VWR Environmental Chamber, Model No. 2020, Shelden Manufacturing Company Inc., Cornelius, Oregon) at a temperature of $28^{\circ} \mathrm{C}$, a relative humidity of $70 \%$ and a photoperiodic regime of $10 \mathrm{~h}$ day light and $14 \mathrm{~h}$ of darkness. The larvae of each species were weighed as a group every 3 days. The average length of the larvae was also measured and recorded. The changes in the groups were observed and recorded.

Mass rearing: The rest of the larvae of each species were taken from the starter culture and used as stock for mass rearing of the insects for determination of nutritional value. They were all of similar age and reared to maturity. The mass rearing medium was placed in the mass rearing cages $(65 \times 45 \times 45 \mathrm{~cm}$ deep plastic container with perforated sides and cover). The mass rearing cages were placed in an environmentally controlled chamber (VWR Environmental Chamber, Model No. 2020, Shelden Manufacturing Company Inc., Cornelius, Oregon) at a temperature of $28^{\circ} \mathrm{C}$, relative humidity of $70 \%$ and photoperiodic regime of $10 \mathrm{~h}$ of light and $14 \mathrm{~h}$ of darkness. Two, one litre jars were provided for the larvae to pupate inside. The pupae were collected from the bottles and placed in special containers filled with medium until the emergence of the moths. Adults were allowed to emerge into the jars where they were paired for appropriate mating. The female moths were collected and placed in the oviposition cases.

Chemical analyses: The chemical analyses performed in this study included, moisture, ash, protein and fat contents and mineral and amino acid profiles.

Moisture content: A sample of thirty mass reared larvae from each species representing a full range of weighs were chosen the moisture analysis. The oven dry method described by APHA (1990) was followed. The worms were frozen and dried in a freeze dryer (Labconco FreeZone, Cat No. 10-271-16, Fisher Scientific, Montreal, Quebec) for $24 \mathrm{~h}$. The weight of each group was recorded using a Mettler scientific balance (AE 2005, Mettler Instruments, AG, Greifensee, Zurich, Switzerland). They were then placed in a convection oven (Isotempoven, Model No. 655F, Fisher Scientific, Montreal, Quebec) for $24 \mathrm{~h}$ at $105^{\circ} \mathrm{C}$. The dried samples were then removed from the oven, left to cool in a dessicator and weighed. The moisture content was calculated as follows:

$\mathrm{MC}=\frac{\mathrm{M}_{1}-\mathrm{M}_{2}}{\mathrm{M}_{1}} \times 100$

Where:

MC $=$ The moisture content (\%)

$\mathrm{M}_{1}=$ The initial weight (g)

$\mathrm{M}_{2}=$ The weight of the dried sample (g)

Ash content: The ash content was determined gravimetrically on the dried worm samples according to the procedure described in APHA (1990). The dried samples were placed in a muffle furnace (Isotemp muffle furnace, Model No. 186A, Fisher Scientific, Montreal, Quebec) for $30 \mathrm{~min}$ at $550^{\circ} \mathrm{C}$. They were removed from the muffle furnace, left to cool in a dessicator and then weighed using a Mettler scientific 
balance (AE 2005, Mettler Instruments, AG, Greifensee, Zurich, Switzerland). The ash content was calculated as follows:

$\mathrm{AC}=\frac{\mathrm{M}_{3}}{\mathrm{M}_{1}} \times 100$

Where:

$\mathrm{AC}=$ The ash content (\%)

$\mathrm{M}_{3}=$ The weight of the material remaining after burning the dry sample (g)

Protein content: The protein analysis was carried out using 30 mass reared larvae from each species representing a full range of weights. The worms were frozen and dried in a freeze dryer (Labconco FreeZone, Cat No. 10-271-16, Fisher Scientific, Montreal, Quebec) for 24 h. The weight of each group (30 worms) was then recorded using a Mettler scientific balance (AE 2005, Mettler Instruments, AG, Greifensee, Zurich, Switzerland). Each group was ground using a laboratory grinder (Waring Laboratory, Cat No. 14509-18, Fisher Scientific, Montreal Quebec), placed in a plastic pouch and stored in a freezer until need for protein analysis. The total protein was determined using the Tecator Kjeltec Auto Analyzer (Model-1026, Fisher Scientific, Montreal, Quebec). The freeze dried worms were transferred to the macro $250 \mathrm{~mL}$ digestion tubes. One "Kjeltab" (containing $3.5 \mathrm{~g} \mathrm{~K}_{2} \mathrm{SO}_{4}$ and $0.0035 \mathrm{~g}$ Se) and $3.0 \mathrm{~mL}$ of distilled water were added to the samples in the digestion tubes. The samples were digested at $420^{\circ} \mathrm{C}$ for $30 \mathrm{~min}$ in a digestion block heater (Tecator Digester System, 20 Model-1016, Fisher Scientific, Montreal, Quebec). The digestion tubes were removed and allowed to cool for $10 \mathrm{~min}$. Then, $30 \mathrm{~mL}$ of distilled water was added to each of the digestion tubes. The test tubes and the digests were transferred to the Auto Analyzer. The constants A and B for the equipment were set at 0.00 and 1.862 , respectively. The titrant acid and the predetermined blank sample were set at 0.2127 and $0.01 \mathrm{M}$, respectively. Distillation, titration and calculation were performed automatically. The protein percentage was computed from the following equation:

$$
\mathrm{PC}=\frac{\text { Displayed result }}{\mathrm{W}_{\mathrm{s}}}
$$

Where:

$\mathrm{PC}=$ The protein content (\%)

$\mathrm{W}_{\mathrm{s}}=$ The weight of the freeze dried worms (g)

Fat content: The fat content was carried out, using 30 mass reared larvae from each species representing a full range of weights. The worms were frozen and dried in a freeze dryer (Labconco FreeZone, Cat No. 10-271-16, Fisher Scientific, Montreal, Quebec) for $24 \mathrm{~h}$. The weight of each group (30 worms) was recorded using a Mettler scientific balance (AE 2005, Mettler Instruments, AG, Greifensee, Zurich, Switzerland). Each group was ground in a laboratory grinder (Cat No. 14-509-18, Waring Laboratory, Fisher Scientific, Montreal Quebec). The fat content was determined using an ether extraction technique according to the procedure described in the Official Method of the Association of Official Analytical Chemists (AOAC) (1975). Hot ether was percolated through a porous receptacle filled with the dry ground meal worms for $24 \mathrm{~h}$. The fat was released from the dry matter and collected in a flask at the bottom of the apparatus. The receptacle was removed, dried in a vacuum oven (Isotemp oven, Model No. 655F, Fisher Scientific, Montreal, Quebec) for $24 \mathrm{~h}$ at $105^{\circ} \mathrm{C}$ and then reweighed. The change in weight corresponded to the fat content of the original sample. The fat percentage was computed from the following equation:

$$
\mathrm{FC}=\frac{\mathrm{W}_{\mathrm{f}}}{\mathrm{W}_{\mathrm{s}}} \times 100
$$

Where:

$\mathrm{FC}=$ the fat content (\%)

$\mathrm{W}_{\mathrm{f}}=$ the weight of fat extracted $(\mathrm{g})$

Amino acids: The amino acids (alanine, arginine, cysteine, glutamic, glycine, histidine, isoleucine, leucine, lysine, methionine, phenylalanine, serine, threonine, tryptophan, tyrosine and valine) were determined using the HFB-IBA (Heptafluorobutyric isobutyl esters of amino acids) Amino Acid derivatization Kit (Cat. No. 18094, Alltech Associates, Inc., Deerfield, Illinois). First, $50 \mathrm{mg}$ of dried larvae were weighed using a Mettler scientific balance (AE 2005, Mettler Instruments, AG, Greifensee, Zurich, Switzerland) and placed in a small reaction vial. An amount of $3 \mathrm{~mL}$ of $0.2 \mathrm{M} \mathrm{HCl}$ was added to each vial and the solutions were heated to approximately $110^{\circ} \mathrm{C}$ using a block heater (Model 16500-10, Hach Chemical Co., Loveland, CO) for $30 \mathrm{~h}$. Then, the vials were removed from the heater and dried under a stream of dry nitrogen. $1.25 \mathrm{~mL}$ of acetyl chloride (Cat. No. 18094B, Alltech Associates Inc. Deerfield, Illinois) was slowly added to $50 \mathrm{~mL}$ of isobutanol and the mixture was added to each vial, (which contained dry sample). The vials were capped and heated at $110^{\circ} \mathrm{C}$ for $45 \mathrm{~min}$. The vials were uncapped and heated at $115^{\circ} \mathrm{C}$ under a stream of nitrogen to remove excess reagent. Then, the vials were removed from the heater and cooled in an ice bath (Microprocessor Controlled 280 Series Water 
Bath, Precision, City, State) for approximately 5 min. As $3 \mathrm{~mL}$ of methylene chloride and $2 \mathrm{~mL}$ of HFBA (Cat. No. 18094A, Alltech Associates Inc, Deerfield, Illinois) were added to each vial. The vials were then capped and heated at $100^{\circ} \mathrm{C}$ for $4 \mathrm{~h}$. The vials were removed from the heater and after cooling to ambient temperature, excess reagent was evaporated under a stream of dry nitrogen. The dried samples were redissolved by adding $2 \mathrm{~mL}$ of ethyl acetate and injected in the gas chromatograph (Model-HP5890 Series II, Hewlett, Palo Alto, CA). The amino acids profile was determined from the output of the gas chromatograph.

Elemental analysis: The elemental analyses were performed on the freeze dried larvae in the Mineral Engineering Center of Dalhousie University, Halifax, Nova Scotia. All elements were determined by flame atomic absorption spectrometer (Spectr AA 55B, Varian Australia, Ply Ltd., Mulgrave, Australia) with a deflection limit of $1 \mathrm{ppm}$. Sulphur was determined with a Leco Sulphur Analyzer (Model 337-500, Leco Corporation, St. Joseph, MI, USA) along with an induction furnace (Leco $\mathrm{HF}_{2} \mathrm{O}$ furnace, Leco Corporation, St. Joseph, MI, USA).

\section{RESULTS}

Life cycle and culture structure: The stages of the life cycle and the changes among the individuals in each group of insects were observed and recorded. These included the number of eggs per waxed paper, the total number of eggs, the average weight of larvae, the average length of larvae, the average lengths of oviposition, pupal and adult stages, the mortality among the larvae and the appearance. The changes were of three types: (a) Death of one or more of the worms, (b) pupation of one or more of the worms and (c) the pupation of one or more of the worms. The dead worms were counted and discarded. The number of worms to enter the pupal stage of their development and the number of adults emerging from the pupal stage were recorded for each group. The results are shown in

Table 2 and 3. The population structure is shown in Fig. 2. Only one larva died (10\%) from each group of insects. The phenomenon of cannibalism among the American bollworm reported by Chipeleme (Chipeleme, 1981) was not observed in this study. The pupation stage started at different times for the two species. The pupation started on days 33 and 12 and emergence of adults started on days 51 and 21 for the maize stalk borer and American bollworm, respectively. The pupation stage lasted for 21 and 15 days and the adult stage lasted for 12 and 15 days for the maize stalk borer and American bollworm, respectively. The maximum length was 30 and $50 \mathrm{~mm}$ and the maximum weight was 2.50 and $5.30 \mathrm{~g}$ for the maize stalk borer and American bollworm, respectively.

Growth rate: For each species of insects, the average weight and average length were plotted against time as shown in Fig. 3. It was noticed that for the first 3-6 days, the average weight did not show any significant increase. This initial period was required for the adjustment to the new environment and medium. The weight of larva increased with time up to a maximum value and then decreased once the larva was preparing for the pupation stage. The maximum weight and maximum length were reached at the same time.

Table 2: Larval growth, pupation and emergence of adults

\begin{tabular}{|c|c|c|c|c|c|c|}
\hline \multirow{2}{*}{ Day } & \multicolumn{3}{|c|}{ Maize stalk borer } & \multicolumn{3}{|c|}{ American bollworm } \\
\hline & Weight (g) & Length (mm) & Stage of growth & Weight (g) & Length (mm) & Stage of growth \\
\hline 0 & 0.35 & 3.50 & $10 \mathrm{~L}$ & 0.98 & 4.50 & $10 \mathrm{~L}$ \\
\hline 3 & 0.35 & 3.50 & $10 \mathrm{~L}$ & 0.98 & 4.50 & $10 \mathrm{~L}$ \\
\hline 6 & 0.36 & 4.10 & $10 \mathrm{~L}$ & 1.96 & 9.80 & $9 \mathrm{~L}$ \\
\hline 9 & 0.54 & 6.50 & $10 \mathrm{~L}$ & 3.08 & 20.00 & $9 \mathrm{~L}$ \\
\hline 12 & 0.76 & 9.00 & $10 \mathrm{~L}$ & 4.46 & 30.00 & $8 \mathrm{~L}+1 \mathrm{M}$ \\
\hline 15 & 1.00 & 11.00 & $10 \mathrm{~L}$ & 4.92 & 40.00 & $6 L+3 P$ \\
\hline 18 & 1.27 & 13.50 & 9L & 5.20 & 48.00 & $9 \mathrm{P}$ \\
\hline 21 & 1.58 & 15.40 & $9 \mathrm{~L}$ & $5.30 *$ & $50.00 *$ & $8 \mathrm{P}+1 \mathrm{M}$ \\
\hline 24 & 1.91 & 18.00 & 9L & 5.20 & 41.00 & $7 \mathrm{P}+2 \mathrm{M}$ \\
\hline 27 & 2.19 & 20.50 & $9 \mathrm{~L}$ & 4.80 & 38.00 & $5 \mathrm{P}+4 \mathrm{M}$ \\
\hline 30 & 2.33 & 23.00 & $9 \mathrm{~L}$ & 4.20 & 36.00 & $9 \mathrm{M}$ \\
\hline 33 & 2.40 & 26.50 & $7 \mathrm{~L}+2 \mathrm{P}$ & 3.50 & 35.00 & $8 \mathrm{M}$ \\
\hline 36 & 2.46 & 28.50 & $2 \mathrm{~L}+7 \mathrm{P}$ & & & $7 \mathrm{M}$ \\
\hline 39 & $2.50 *$ & $30.00 *$ & $9 \mathrm{P}$ & & & $5 \mathrm{M}$ \\
\hline 42 & 2.48 & 29.00 & $9 \mathrm{P}$ & & & $2 \mathrm{M}$ \\
\hline 45 & 2.28 & 27.00 & $9 \mathrm{P}$ & & & \\
\hline 48 & 2.01 & 26.00 & $9 \mathrm{P}$ & & & \\
\hline 51 & & & $2 \mathrm{P}+7 \mathrm{M}$ & & & \\
\hline 54 & & & $9 \mathrm{M}$ & & & \\
\hline 57 & & & $7 \mathrm{M}$ & & & \\
\hline 60 & & & $6 \mathrm{M}$ & & & \\
\hline
\end{tabular}




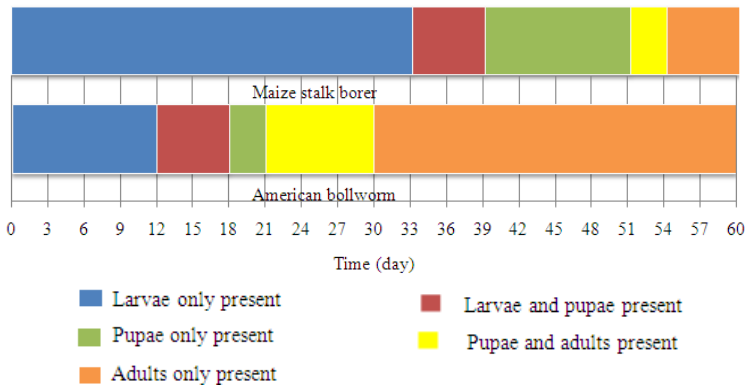

Fig. 2: Changes in population structure

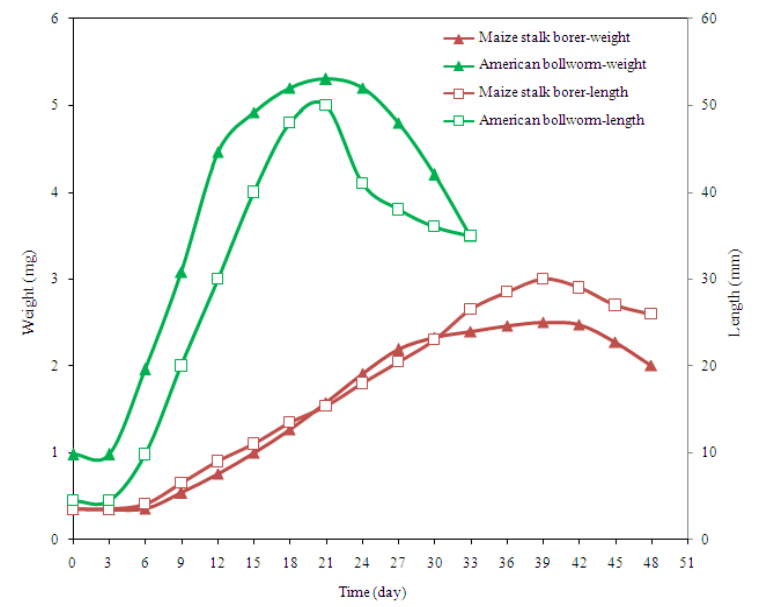

Fig. 3: The changes in the weight and length of the larvae

Table 3: Life cycle characteristics

\begin{tabular}{lcc}
\hline Characteristics & Maize stalk borer & American bollworm \\
\hline Number of eggs per sheet & 30.00 & 85.00 \\
Maximum weight (g) & 2.50 & 5.30 \\
Maximum length (mm) & 30.00 & 50.00 \\
Duration of egg stage (d) & 4.00 & 2.00 \\
Duration of larval stage (d) & 30.00 & 9.00 \\
Duration of pupal stage (d) & 21.00 & 15.00 \\
Duration of adult stage (d) & 12.00 & 15.00 \\
Larval mortality (\%) & 10.00 & 10.00 \\
Color & Whitish & Brown \\
\hline
\end{tabular}

The change in growth rate $\left(\mathrm{g} \mathrm{day}^{-1}\right)$ was determined by dividing the weight increase in a given period by the length of the period (3 day). The results are shown in Fig. 4. Initially, the growth rate increased and then decreased when the larvae got older. The negative values indicated weight loss.

Growth and time indices: The first 3-6 days were considered a period of adjustment to the new environment (slow or no growth) and the period of pupation was associated with weight loss. Thus, the period of larval growth (continued growth) was

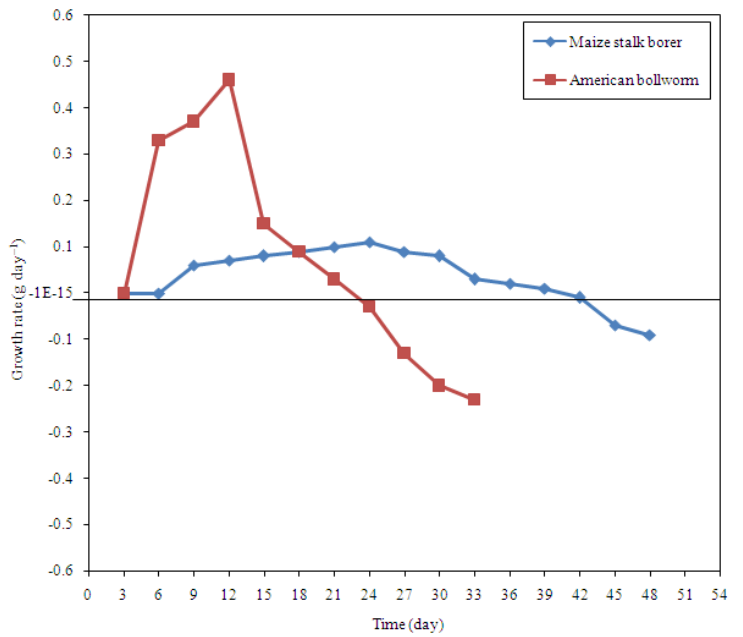

Fig. 4: Growth rate of worms

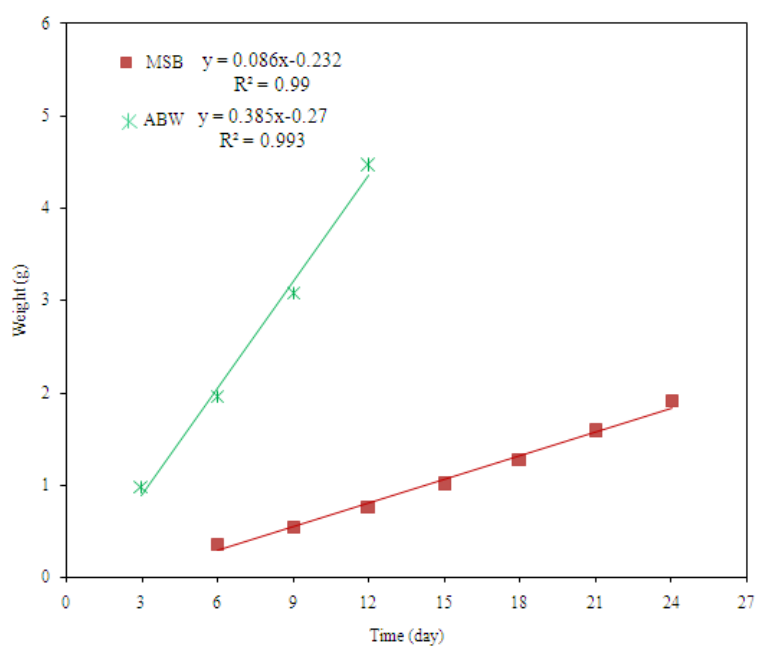

Fig. 5: Determination of average growth rate. $(\mathrm{MSB}=$ Maize stalk borer, $\mathrm{ABW}=$ American bollworm)

linearized as shown in Fig. 5. The slope of the linear line (average growth rate) was divided by the initial weight to obtain the growth index. The time required to reach the maximum weight was divided by the maximum weight of the larva to obtain the larval time index. The time required to reach the maximum weight was also divided by the total population weight (number of eggs produced by female moth $\times$ larval weight) to obtain the population time index. The results are shown in Table 4. The average rate of growth achieved was 0.09 and $0.39 \mathrm{~g} \mathrm{day}^{-1}$ for the maize stalk borer and the American bollworm, respectively. The time required to reach maximum size was 39 and 21 days for the maize stalk borer and American 
Table 4: Growth and time indices

\begin{tabular}{|c|c|c|}
\hline Parameter & Maize stalk borer & American bollworm \\
\hline $\begin{array}{l}\text { Number of eggs produced } \\
\text { by female moth }\end{array}$ & 800.00 & 1000.00 \\
\hline Maximum weight (g) & 2.50 & 5.30 \\
\hline Time to reach maximum size (d) & 39.00 & 21.00 \\
\hline Growth rate $\left(\mathrm{g} \mathrm{day}^{-1}\right)$ & 0.09 & 0.39 \\
\hline Growth Index ( $\mathrm{g} \mathrm{g}^{-1}$ day $^{-1}$ ) & 4.07 & 2.55 \\
\hline Larval Time Index (day g ${ }^{-1}$ ) & 15.60 & 3.96 \\
\hline Population Time Index $\left(\mathrm{min} \mathrm{g}^{-1}\right)$ & 0.47 & 0.10 \\
\hline
\end{tabular}

Growth index $=$ (Maximum weight of Larva)/(initial weight of larva $x$ time required for maximum growth); Laval time index: (Time required for maximum Growth)/(maximum weight of larva) population time index: (Time required for maximum growth)/ (Maximum weight of larva $\times$ number of eggs)

Table 5: Nutritional analysis of freeze dried larvae

\begin{tabular}{llc}
\hline & & Content (\%) \\
\cline { 2 - 3 } Constituent & Maize stalk borer & American bollworm \\
\hline Moisture & 11.3 & 10.6 \\
Ash & 10.7 & 6.8 \\
Carbohydrate & 30.6 & 30.1 \\
Protein & 33.0 & 38.0 \\
Fat & 14.4 & 14.5 \\
\hline Moisture content of live maize stalk borer larvae: $61.0 \%$; Moisture \\
content of live American bull worm larvae: $60.4 \%$
\end{tabular}

bollworm, respectively. The time required to produce one gram of larva was 15.60 and 3.96 days for the maize stalk borer and American bollworm, respectively. When the population size (number or eggs produced by female moth) was considered, the time required to produce one gram of insects was 0.47 and 0.10 for the maize stalk borer and American bollworm, respectively.

Larval composition: The results of moisture, ash, carbohydrate, protein and fat contents were calculated on dry weight basis when the larvae reached their maximum weights. The results are presented in Table 5. Although the larvae of both insect species were dried under the same conditions, the maize stalk borer had slightly higher moisture content (12.2\%) than the American bollworm (11.6\%). The maize stalk borer also had higher ash, carbohydrate and fat contents (11.7, 22.6 and $16.7 \%$, respectively) than the American bollworm (7.5, 20.1 and 16.1\%, respectively). The American bollworm had higher protein content (44.7\%) than the maize stalk borer (36.8\%).

The energy available in the carbohydrate, protein and fat in the larvae are shown in Table 6. About 383 and $402 \mathrm{kcal} / 100 \mathrm{~g}$ larvae are provided by the carbohydrate, protein and fat contents of the maize stalk borer and the American bollworm, respectively. The female moths of the maize stalk borer produced 800 eggs while the female moth of the American bollworm produced 1000 eggs. Therefore, about 7660 and
$21306 \mathrm{kcal}$ will be available in the larvae produced by the female moth of the maize stalk borer and American bollworm, respectively.

The quality of the protein and, thus, the nutritional value of the insects is determined by the amino acid composition as reported by DeGuevara et al. (1995). The larvae of both worms contain all the essential amino acids needed for human growth as shown in Table 7.

Table 8 shows the profile of some of the essential elements found in the larvae of the maize stalk borer and American bollworm. The total elemental composition was 121.2 and $72.29 \mathrm{mg} \mathrm{g}^{-1}$ dry matter for the maize stalk borer and American bollworm, respectively. The larvae of both worms contain most of the essential elements. However, the maize stalk borer has higher concentrations of all the elements compared to the American bollworm.

\section{DISCUSSION}

The results showed an initial period of adjustment by the young larvae to the new environment. This was followed by a period of increased weight. The increase in the body weight during the growth period appeared to be linear. After the initial growth period, the larvae started to decrease in weight after they reached their maximum size. An interesting characteristic of the caterpillars studied is that they reached maximum weight and maximum length at the same time. For the commercial production of the maize stalk borer and the American bollworm, the larvae should be harvested when they are 39 and 21 days old, respectively.

Only $10 \%$ mortality was observed with older larvae of both species. A system where eggs are separated from adults and hatched in separate chambers would alleviate the potential danger of losing the population due to microbial infection. The high moisture content of the live larvae $(61.0 \%$ for the maize stalk borer and 60.4 for the American bull worm) could cause handling and storage problems. Drying and grinding the larvae would reduce them to easily manageable forms that would improve their marketability as novel food.

Because the larvae seem to be a promising source of protein for human consumption, further research is required to evaluate their growth characteristics on low substrates. Future research should also evaluate environmental parameters such as temperature, relative humidity and heat and $\mathrm{CO}_{2}$ production on food consumption and protein yield per gram substrate. This information will aid in the design of an optimal insect production system. The results obtained from this study show the potential of using insects as a protein source for human consumption to alleviate protein deficiency 
Am. J. Applied Sci., 7 (1): 1-12, 2010

Table 6: Energy content

\begin{tabular}{|c|c|c|c|}
\hline \multirow{2}{*}{ Source of energy } & \multicolumn{2}{|c|}{ Contents (\%) } & \multirow{2}{*}{ MS } \\
\hline & MSB & ABW & \\
\hline Carbohydrate & 30.6 & 30.1 & 1.3 \\
\hline Protein & 33.0 & 38.0 & 1.4 \\
\hline Fat & 14.4 & 14.5 & 1.4 \\
\hline Total & & & 4.1 \\
\hline \multicolumn{4}{|c|}{$\begin{array}{l}\text { MSB: Maize Stalk Borer; ABW: American Bollworm; Carbohydrate } \\
\text { moisture content }=61 \% \text { for MSB and } 60.4 \% \text { for ABW; Dried moistu } \\
\text { larva }=2.5 \mathrm{~g} \text { for MSB and } 5.3 \mathrm{~g} \text { for ABW; Number of eggs produced b }\end{array}$} \\
\hline \multicolumn{4}{|c|}{ Table 7: Amino acid profile } \\
\hline \multirow{2}{*}{ Amino acid } & \multicolumn{2}{|c|}{ g/100 g dry matter } & \\
\hline & Maize stalk borer & American & \\
\hline Alanine & 6.4 & 6.8 & \\
\hline Arginine & 5.7 & 5.9 & \\
\hline Cysteine & 5.7 & 2.3 & \\
\hline Glycine & 1.9 & 5.0 & \\
\hline Glutamic & 5.1 & 13.1 & \\
\hline Histidine & 12.3 & 1.8 & \\
\hline Isoleucine & 1.9 & 4.4 & \\
\hline Leucine & 4.1 & 6.9 & \\
\hline Lysine & 8.2 & 6.3 & \\
\hline Methionine & 5.3 & 2.2 & \\
\hline Phenylalanine & 2.0 & 9.1 & \\
\hline Serine & 4.6 & 5.1 & \\
\hline Threonine & 3.9 & 4.3 & \\
\hline Tryptophan & 0.4 & 0.4 & \\
\hline Tyrosine & 4.1 & 8.2 & \\
\hline Valine & 4.8 & 5.3 & \\
\hline
\end{tabular}

Table 8: Mineral contents

\begin{tabular}{llc}
\hline & & \\
Element & Mry matter $\left(\mathrm{mg} \mathrm{g}^{-1}\right)$ \\
\hline $\mathrm{K}$ & 57.6 & American bollworm \\
$\mathrm{Ca}$ & 20.0 & 35.2 \\
$\mathrm{P}$ & 10.8 & 7.8 \\
$\mathrm{~S}$ & 7.9 & 4.7 \\
$\mathrm{Mg}$ & 4.7 & 2.3 \\
$\mathrm{Fe}$ & 2.8 & 4.5 \\
$\mathrm{Na}$ & 1.7 & 1.7 \\
Zn & 0.1 & 0.7 \\
Others & 15.6 & 0.0 \\
Total & 121.2 & 16.0 \\
\hline
\end{tabular}

Table 9: Taste of commonly used insects (Holt, 1969; Taylor, 1975)

\begin{tabular}{ll}
\hline Insect & Taste \\
\hline Fried ants & $\begin{array}{l}\text { Described as insipid because they lacked } \\
\text { distinct taste }\end{array}$ \\
Fried agave worm & $\begin{array}{l}\text { Were compared to slightly burned French fries } \\
\text { Fried caterpillars }\end{array}$ \\
$\begin{array}{l}\text { Pried predaceous } \\
\text { diving beetle }\end{array}$ & $\begin{array}{l}\text { Quite good and compared to clams, sunflower } \\
\text { seeds and shrimp }\end{array}$ \\
Fried grasshopper & Taste like sardines or fish \\
Dried bees & Strong disagreeable flavor and too mushy \\
Fried silkworms & Likened to rotten meat \\
Fried butterflies & Taste like the pier smells \\
Fresh grasshoppers & Pleasant taste and delicious \\
Fresh cockchafer worms & Acceptable \\
Termites & Taste like lobsters or snail with a faint smell \\
& of mushrooms \\
\hline
\end{tabular}

in many parts of the world, especially in Latin America, Africa and Asia. Governments in these countries should embark on using these inexhaustible nutritional resources to feed their people. The species that have been proven to be high in protein and nutritional content and show the economics of energy conversion of feed to insect protein are good candidates for mass rearing and marketing

Mass rearing of insects has been practiced for years. Bees are grown in large quantities for distribution as colonies to honey producers (Kok et al., 1991). Booram (1975) Boll weevils have been mass reared for pest control (Miller et al., 1975; Webb et al., 1981). Mealworms have been produced on a commercial scale as food for birds and reptiles (Ebeling, 1975). Some efforts have been made to produce flies from livestock waste for animal consumption (Gantt and King, 1981; Morgan and Eby, 1975; Burchell, 1989). It is, therefore, conceivable that insect farming will be a part of a new agricultural system. It will be possible in the near future to construct small but efficient insect farms that have high volumetric protein production rates. Insects are in size between SCP and farm animals, they yield structured animal protein, require much less energy for processing than SCP and less space than farm animals, still large enough to be reared and harvested using automated systems. They contain proteins, essential amino acids, lipids, minerals, vitamins and energy (Bukkens 1997; DeGuevara et al., 1995; DeFoliart and Professor, 1992).

In the light of current protein deficiency and population growth, there is a need for a novel protein source (as an alternative for meat) that is safe, nutritious, flexible, reliable and consumer accepted. It has been predicted that in the next decades about $40 \%$ of red bovine meat consumption will be replaced by novel protein sources such as insects (Verkerk et al., 2007). Although of small size, insects because of their prodigious numbers, exceed in weight all other animal matter (Banjo et al., 2006). This great mass of material possesses genuine food value. From the eating habits of wild animals by natives in many countries, it seems that 
Am. J. Applied Sci., 7 (1): 1-12, 2010

Table 10: Nutritional value of selected animal food products and insects (Ramos-Elorduy, 1997; Bukkens, 1997) ${ }^{[48]}$

\begin{tabular}{|c|c|c|c|c|c|c|}
\hline Food product & Water (\%) & Ash (\%) & Carbohydrates (\%) & Protein (\%) & Fat (\%) & kcal (100 g) \\
\hline \multicolumn{7}{|l|}{ Selected foods } \\
\hline Beef (total edible, trimmed to retail level) & $56.7-63.9$ & $0.8-0.9$ & 0.0 & 17.4-19.4 & $15.8-25.1$ & $225-301$ \\
\hline Lamb (legs, lean rib and shoulder, trimmed to retail level) & $56.3-62.5$ & $1.2-1.3$ & 0.0 & $15.4-16.8$ & 19.4-27.1 & $247-310$ \\
\hline Pork (shoulder and spare ribs, trimmed to retail level) & 52.6-59.5 & $1.0-1.2$ & 0.0 & $14.6-23.4$ & 22.7-31.4 & 276-347 \\
\hline Chicken (broiler and rosters, light and dark meat without skin) & 73.0 & 1.0 & 0.0 & 20.6-23.4 & $1.9-4.70$ & $117-130$ \\
\hline Fish (lake trout) & 70.6 & 1.1 & 0.0 & 18.3 & 10.0 & 168 \\
\hline Fish (atlantic and Pacific Halibut) & 76.5 & 1.4 & 0.0 & 20.9 & 1.2 & 100 \\
\hline Milk (whole) & 87.2 & 0.7 & 4.9 & 3.5 & 3.7 & 66 \\
\hline Egg (whole) & 73.7 & 1.0 & 0.9 & 12.9 & 11.5 & 163 \\
\hline \multicolumn{7}{|l|}{ Selected insects } \\
\hline Termites (Isoptera)-fried & 15.0 & 7.9 & 11.1 & 30.0 & 36.0 & 508 \\
\hline Grasshoppers (Othorptera)-dried & 7.1 & 9.2 & 12.7 & 54.0 & 17.0 & 327 \\
\hline Butterflies (Lepidoptera)-smoked & 16.7 & 1.9 & 16.9 & 47.7 & 16.8 & 268 \\
\hline Beetles (Coleopteran)-dried & 15.1 & 3.6 & 2.3 & 53.1 & 25.9 & 464 \\
\hline House flies (Dipteral)-dried & 13.7 & 5.3 & 2.4 & 63.1 & 15.5 & 655 \\
\hline Spiders (Melopoensalbostriatus)-roasted & 13.7 & 6.4 & 5.3 & 63.8 & 10.8 & 452 \\
\hline
\end{tabular}

much of the insects are palatable (Table 9) (Holt, 1969; Harris and Ross, 1987). Chemical analyses of many insects have also shown that they compare favourably with traditional foods/animal products (Table 10) (Ramos-Elorduy, 1997; Bukkens, 1997; Taylor, 1975).

Since a wide variety of low substrates are available, materials which are not edible can be converted into human food by insects such as mealworms. Insects are very efficient feed converters to protein (more than five times that of beef) and fast growing organisms (Banjo et al., 2006), two characteristics that allow the design of a farm system that can respond to changes in demand. The integration of insects into the current agricultural production system will increase the complexity of the systems by creating symbiotic relationships with other species. This will improve the efficiency of the agricultural production system and insure its sustainability.

\section{CONCLUSION}

The larvae of both the maize stalk borer and American bollworm reached maximum weight and maximum length at the same time. The increase in the body weight during the growth period appeared to be linear. The larvae started to decrease in weight after they reached their maximum size. For the commercial production of the maize stalk borer and the American bollworm, the larvae should be harvested when they are 39 and 21 days old, respectively.

Only $10 \%$ mortality was observed with older larvae of both species. A system where eggs are separated from adults and hatched in separate chambers would alleviate the danger of losing the population due to microbial infection. Drying and grinding the larvae would reduce them to easily manageable forms and would improve their marketability as novel food.
The results obtained from this study show the potential of using insects as a protein source for human consumption to alleviate protein deficiency in many parts of the world, especially in Latin America, Africa and Asia. Governments in these countries should embark on using these inexhaustible nutritional resources to feed their people. The species that have been proven to be high in protein and nutritional contents and show the economics of energy conversation of feed to insect protein are good candidates for mass rearing.

Because the larvae seem to be a promising source of protein for human consumption, further research is required to evaluate their growth characteristics on low substrates. Future research should evaluate environmental parameters such as temperature, relative humidity and heat and $\mathrm{CO}_{2}$ production on food consumption and protein yield per gram substrate. This information will aid in the design of an economically sustainable insect production system.

\section{ACKNOWLEDGMENT}

This research was supported by the National Science and Engineering Council (NSERC) of Canada.

\section{REFERENCES}

AOAC., 1975. Official Methods of Analysis of the Association of Official Agricultural Chemistry. Association of Official Agricultural Chemistry, Washington DC.

APHA., 1990. Standard Methods for Examination of Water and Wastewater. American Public Health Association, Washington DC.

Banjo, A.D., O.A. Lawal and O.O. Oduola, 2006. Ethno-zoological knowledge and perception of non-arthropod invertebrates among the Ijebus (South-Western Nigeria). Int. Dig. Org. Sci. Inform., 1: 19-24. 
Bhatia, J. and F. Greer, 2008. Use of soy protein based formulas in infant feeding paediatrics. 121: 1062-1068.

Bijimarkers, H., 1985. Insects as pests of cereals in Ethiopia: Identification and control methods, FAO/UNDP Project Report, ETH/86/029, Adises Ababa, Ethiopia.

Booram, C.V., 1975. The value of Hermeia illucers as an alternative protein source. ASAE paper No. 75-45. ASAE, St. Joseph, Michigan.

Bukkens, S.G.F., 1997. The nutritional value of edible insects. Ecol. Food Nutr., 36: 287-319.

Burchell, R.L., 1989. Production of a protein substrate from poultry manure through the intensive production of insects. Final design project report. Technical University of Nova Scotia, Halifax, Nova Scotia.

Chipeleme, A.C., 1981. An evaluation of some locally available worms as human protein source. Technical Report, University of Zambia, Lusaka, Zambia.

De Kuijer O.C.H. de and D.K. Wielenga, 1999. A comparison of the environmental impact of meat and meat alternatives and the attractiveness of the alternatives to the consumers VROM, Products Policy 1999/35, The Hague, Netherlands.

DeFoliart, G.R. and E. Professor, 1992. Insects as human food: Gene DeFoliart discusses some nutritional and economic aspects. Crop Prod., 11: 395-399.

DeFoliart, G.R., 1999. Insects as food: why the western attitude is important. Ann. Rev. Entomol., 44: 21-50.

DeGuevara, L.O., P. Padilla, L. Garcia, J.M. Pino and J. Ramos-Elorduy, 1995. Amino acid determination in some edible Mexican insects. Amino Acids, 9: 161-173.

Dimietry, N., 2005. Growth and development of the American bollworm Heliothis armigera under laboratory mass rearing conditions. Cell. Mol. Life Sci., 32: 1006-1007.

Ebeling, W., 1975. Urban entomology. University of California, Berkeley, pp: 695.

Ebenebe, A.A, J. Van der Berg and T.C. de K. Van der Linde. 2000. Seasonal flight activity of the maize stalk borer Busseola fusca (fuller) (lepidoptera: noctuidae), in Losotho. Afr. Entomol., 8: 63-68.

Eby, I.T. and W.L. Dandy, 1962. An attempt to mechanized nutrient recovery from animal waste by the use of house fly larvae. Technical Report 20705. Beltsville Agricultural Research Center, Beltsville, Maryland.

FAO/SD., 2001. Targeting the rural poor: The role of education and training. Sustainable Development Department, Food and Agriculture Organization of the United Nations.
Ferrianti, M.P. and A. Fiechter, 1983. Production and Feeding of Single Cell Protein. Applied Science Publications, London, ISBN: 085334231, pp: 201.

Flint, W.P. and C.L. Metcalf, 1979. Destructive and Useful Insects. McGraw-Hill Publishing Company, New York.

Gantt, C.W. and W.E.G. King, 1981. Diet dispenser for a multiple insect species rearing program. Trans. ASABE., 24: 0194-0196.

Gupta, G.P., B. Ajanta and R. Seemac, 2004. Development of artificial diet for mass rearing of American bollworm Helicoverpa armigera. Ind. J. Agric. Sci., 74: 548-551.

Harrel, E.A., W.D. Perkins and A.N. Sparks, 1980. Improved equipment and techniques for mechanizing the boll weevil larval rearing system. Trans. ASAE., 23: 1554-1556.

Harris, M. and E.B. Ross, 1987. Food and evolution: Toward a Theory of Human Food habits. Temple University Press, Philadelphia, Pennsylvania, pp: 633.

Haydaks, H.H., 1936. A food for rearing laboratory insects. J. Ecol. Entomol., 29: 1026-1028.

Herbert, V., 1998. Vitamin B-12: Plant sources, requirements and assay. Am. J. Clin. Nut., 48: 852-858.

Holt, V.M., 1969. Why not Eat Insects? 1st Edn., EW Classey, England, pp: 99. http://www.entomology.ucr.edu/ebeling/

Kok, R., U.S. Shivhare and K. Lomaliza, 1991. Mass and component balances for insect production. Can. Agric. Eng., 33: 185-192.

Latham, M.C., 1997. Human Nutrition in the Developing World. Food and Agricultural Organization of the United Nations, Rome, Italy. pp: 522. ISBN-13: 978-9251038185

Lipke, H., 1957. Nutritional considerations for rearing insects. Proc. Entomol. Soc. Am., 12: 90-91.

Mendez, M.A., M.S. Anthony and L. Arab, 2002. Soybased formulae and infant growth and development: A Review. J. Nat., 132: 2127-2130.

Miller, J.A., C.D. Schmidt and J.L. Eschle, 1975. Systems for large scale rearing of hornfly Haematobia irritans. ASAE Tech paper No. 75.415. ASAE, St. Joseph. Illinois.

Morgan, N.O. and H.J. Eby, 1975. Fly protein production from mechanically mixed animal wastes. Israel J. Entomol., 10: 73-81.

NLM., 2007. Medical encyclopaedia. US National Library of Medicine. Accessed February 20, 2009. http://www.nlm.nih.gov/medlineplus/ency/article/0 02467.htm

Pariser, E.R., M.B. Wallerstein, C.J. Corkery and N.L. Brown, 1977. Fish Protein Concentrate: Panacea for Protein Malnutrition? The MIT Press, Boston, Massachusetts. 
Ramos-Elorduy, J., 1997. Insects: A sustainable source of food? Ecol. Food Nutr., 97: 247-276.

Robinson, P.D., 1987. The metabolism of ingested and injected larvae of Heliothis armigera. Physiol. Entomol., 12: 22-26.

Sikka, K.C., R. Singh, D.P. Gupta and S.K. Duggal, 1979. Comparative nutritive values of fish protein concentrate from different species of fish. J. Agric. Food Chem., 27: 946-949.

Tannenbaum, S.R. and D.I.C. Wang, 1975. Single Cell Protein Production. The MIT Press, Boston, Massachusetts, pp: 707

Taylor, R.L., 1975. Butterflies in my Stomach: Insects in Human Nutrition. Woodbridge Press Publishing Company, London, pp: 224.

Tracy, W.W., 1907. Tomato Culture: A practical treatise on the tomato, its History, Characteristics, Planting, Fertilization, Cultivation in Field, Garden and Green House, Harvesting, Packing, Storing, Marketing, Insect Enemies and Diseases, with Methods of Control Remedies, Etc., Etc. O. Judd Company, New York, pp: 150.
USDA., 1899. Heliothis armiger. Yearbook of the United States Department of Agriculture 1898. Government Printing Office, Washington DC. http://etc.usf.edu/clipart/46400/46400/46400_boll_ stages.htm

Verkerk, M.C., J. Tramper, J.C.M. Van Trijp and D.E. Marlens, 2007. Insect cells for human food. Biotechnol. Adv., 25: 198-202.

Webb, J.C., H.R. Agee, N.C. Leppla and C.O. Calkins, 1981. Monitoring insect quality. Trans. ASAE., 24: 476-479.

WHO., 2002. Childhood nutrition and progress in implementing the International Code of Marketing of Breast-milk Substitutes. World Health Organization, Geneva, A55/14.

WHO., 2007. World population prospects: 2006 revision highlights. Department of Economic and Social Affairs, Population Division. United Nations, New York.

WHO/FAO., 2007. Protein and Amino Acid Requirements in for Human Nutrition. World Health Organization, Geneva, pp: 265. ISBN 9241209356 